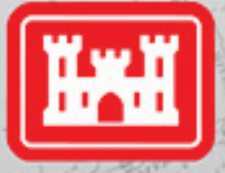

US Army Corps of Engineers ${ }_{\circledast}$

\section{Seamless Digital Elevation Model (DEM) Creation for the Mississippi River in Louisiana to Support Hydrologic Modeling}

by David Arnold

MRG\&P Tech Note No. 8 • November 2020

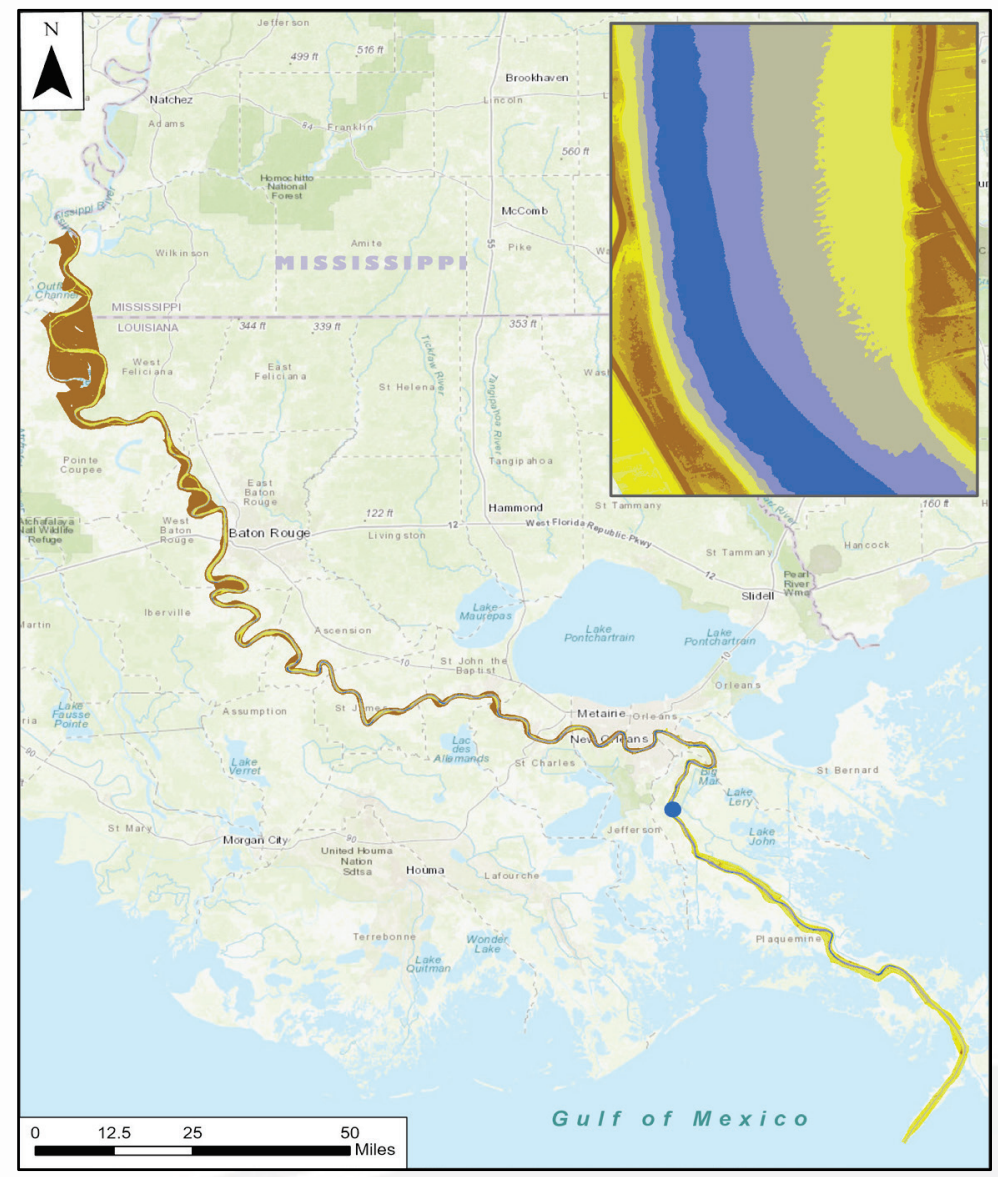

Mississippi River

Geomorphology \& Potamology Program 
INTRODUCTION: The US Army Corps of Engineers (USACE), Mississippi River Geomorphology and Potamology (MRG\&P) Program, addresses the need for the USACE to have access to the most up-to-date and technically competent scientific data and analysis for providing navigation and flood risk management in an environmentally responsible manner (USACE MVD 2020). MRG\&P seeks to better understand river behavior by studying existing and historical data. This is accomplished by collecting and studying numerous sources of data including in situ gauge and sediment data, ecological and geomorphological data, and in the case of this technical note, a Geographic Information System-produced Digital Elevation Model (DEM). A DEM can interchangably be called a Digital Terrain Model, but it will be referred to as a DEM in this publication. The DEM is composed of a grid of pixels spaced at regular intervals, with the pixel value representing elevation at that point (Bilskie and Hagen 2013). Hydrologic modeling of rivers is common practice throughout the world, and the Mississippi River is no exception. There are at least three distinct models for which this project provides topographic and bathymetric data.

Adaptive Hydraulics $(\mathrm{AdH})$ is a modern, multi-dimensional modeling system for saturated and unsaturated groundwater, overland flow, three-dimensional (3D) Navier-Stokes flow, and twodimensional (2D) or 3D shallow water problems. Developed by the Coastal and Hydraulics Laboratory at the US Army Engineer Research and Development Center in Vicksburg, Mississippi, the 2D shallow water module of AdH was released to the public in September 2007 (ERDC 2014). Additional development later provided 3D representations of model physics and includes river basins, reservoirs, estuaries, and groundwater features. The AdH numerical model accounts for numerous variables, which include friction caused by stream bed conditions; sediment type, size and load; structures affecting stream flow; and vessel movement. The model allows for varying mesh resolutions and time-steps, resulting in the most efficient model run possible.

First released in March 2011 by Deltares, an independent institute for applied research associated with the University of Delft in The Netherlands, Delft3D hydrological modeling software has been used around the world for modeling of hydrologic events on rivers, estuaries, and coastal zones in rural and urban areas. Delft3D is an integrated modeling suite, which simulates 2D and 3D flow, sediment transport and morphology, waves, water quality, and ecology (Deltares 2019). The primary module in the software is Delft3D-FLOW, but there are five other modules that come with the package, all of which are integrated and linked.

The Hydrologic Engineering Center, River Analysis System (HEC-RAS) hydrodynamic model was created by the USACE Institute for Water Resources Hydrologic Engineering Center as a River Analysis System. The model has a graphical user interface and can run models in both onedimensional steady flow and 2D with either steady or unsteady flow (USACE HEC 2020). The software can also model sediment transport and water quality.

All three models require an elevation layer as input, with the most current data normally being selected. The purpose of this project was to create a seamless DEM for the Mississippi River from Lake Mary on the Mississippi side of the river to the point where the Mississippi River enters the Gulf of Mexico through the Southwest Pass. The most recent bathymetry was used for the river channel, and the area from the edge of the channel to the levee structures on either side of the river was mapped with LiDAR. The USACE New Orleans District (MVN) provided the data, which 
were collected between March 4, 2012, and September 9, 2016. The final output for this project included seamless DEMs at a spatial resolution of $1 \mathrm{~m}, 2 \mathrm{~m}, 5 \mathrm{~m}$, and $10 \mathrm{~m}$.

DATA COLLECTION: Two different methods were used to collect the four distinct datasets used to create the final DEMs ${ }^{\dagger}$. The Mississippi River channel bathymetry was collected using multibeam sonar, which uses transducers to convert an electrical signal into a sound known as a "ping." Depth is determined by the time it takes the sound to return to the transducer and be converted back into an electrical signal. These data points are used to create a surface of the channel bottom. Multibeam sonar uses several transducers at once, which allows a large swath of the river bed to be measured at one time, in a direction perpendicular to the boat's direction of movement (NOAA 2015).

The multibeam sonar data were collected from Lake Mary, just east of the Mississippi River in Mississippi to the point where the river empties into the Gulf of Mexico through the Southwest Pass. It was collected between September 17, 2012, and September 18, 2013, by a Trimble DSM 232 with Omnistar HP correction, delivering an accuracy of $10 \mathrm{~cm}$. The results were delivered in ASCII text files, which were subsequently converted to Geo Tagged Image File Format files that were mosaicked together with the Environmental Systems Research Institute (ESRI) ArcGIS software. The data were in the State Plane Lousiana South projection with a native spatial resolution of $2 \mathrm{ft}$. Spatial resolution refers to the size of individual cells in a raster dataset and the ratio of screen pixels to image pixels at the current map scale (ESRI 2016), as shown in Figures 1 and 2.

\footnotetext{
${ }^{*}$ For a full list of the spelled-out forms of the units of measure used in this document, please refer to US Government Publishing Office Style Manual, 31st ed. (Washington, DC: US Government Publishing Office 2016), 248-52, https://www.govinfo.gov/content/pkg/GPO-STYLEMANUAL-2016/pdf/GPO-STYLEMANUAL-2016.pdf. ${ }^{+}$Cover Figure: Overview of the Mississippi River DEM at a scale of 1:1,150,000, with an inset view at 1:13,500 showing DEM details, the location of which is represented by the blue dot.

${ }^{\ddagger}$ For a full list of the unit conversions used in this document, please refer to US Government Publishing Office Style Manual, 31st ed. (Washington, DC: US Government Publishing Office 2016), 345-7, https://www.govinfo.gov/content/pkg/GPO-STYLEMANUAL-2016/pdf/GPO-STYLEMANUAL-2016.pdf.
} 


\section{MRG\&P}

\section{Mississippi River Geomorphology \& Potamology Program}

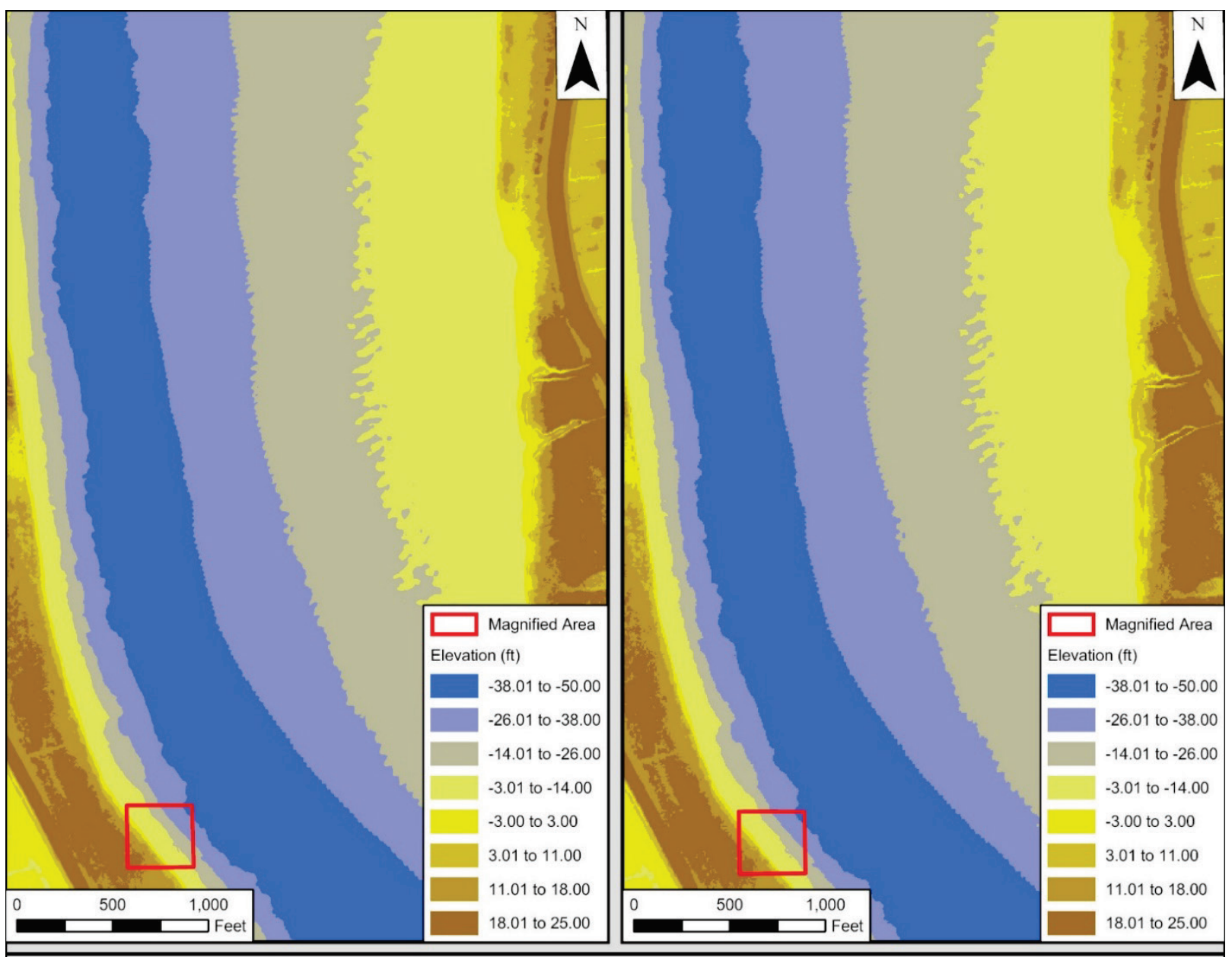

Elevation and bathymetric data at a scale of 1:9,000 show a cross section of the Mississippi River from levee to levee. Data in the upper left corner are at a spatial resolution of $1 \mathrm{~m}$, while data in the upper right corner have a resolution of $2 \mathrm{~m}$. To better display the increasing granularity associated with an increased spatial resolution, the bottom two images are at a scale of 1:1,000.

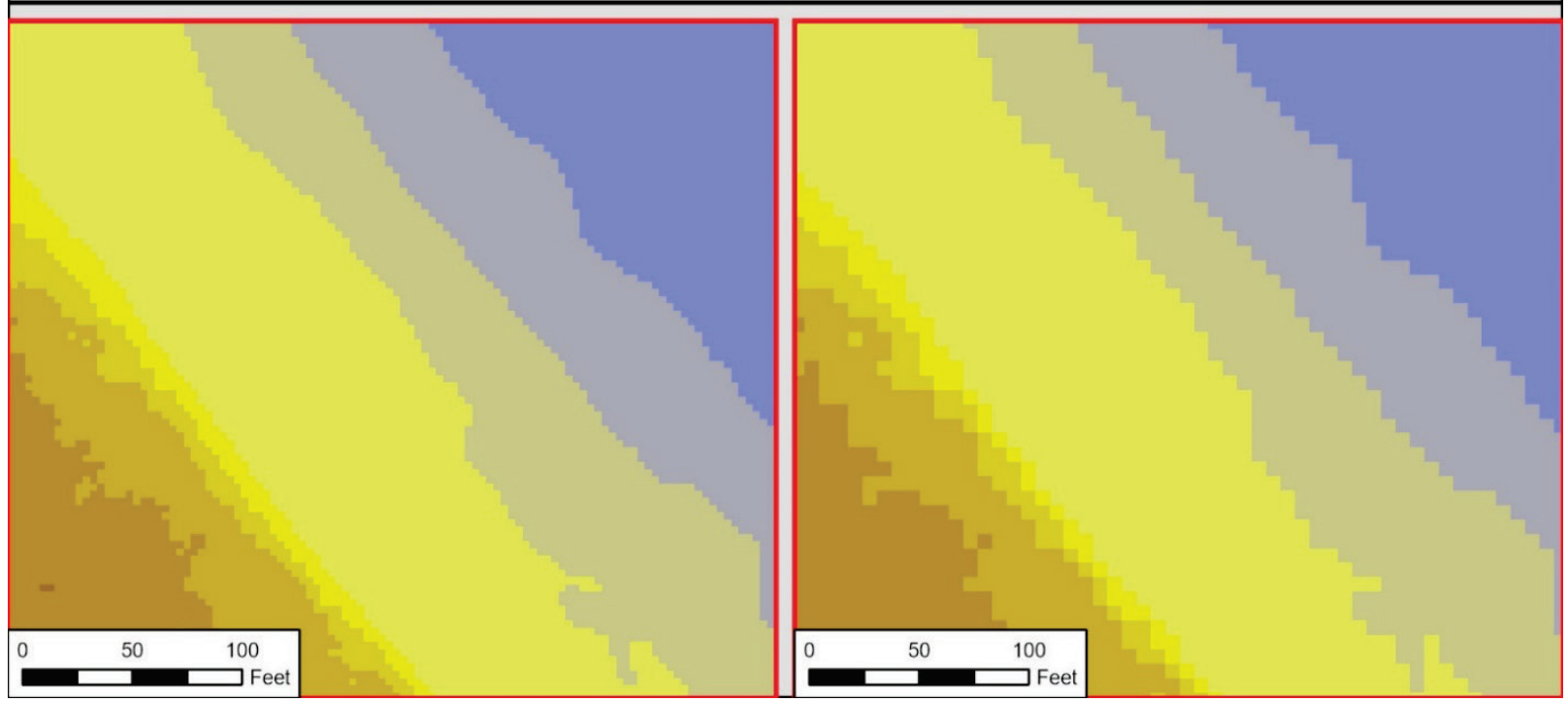

Figure 1. One- and two-meter resolution examples with larger scale insets outlined in red. 


\section{MRG\&P}

\section{Mississippi River Geomorphology \& Potamology Program}

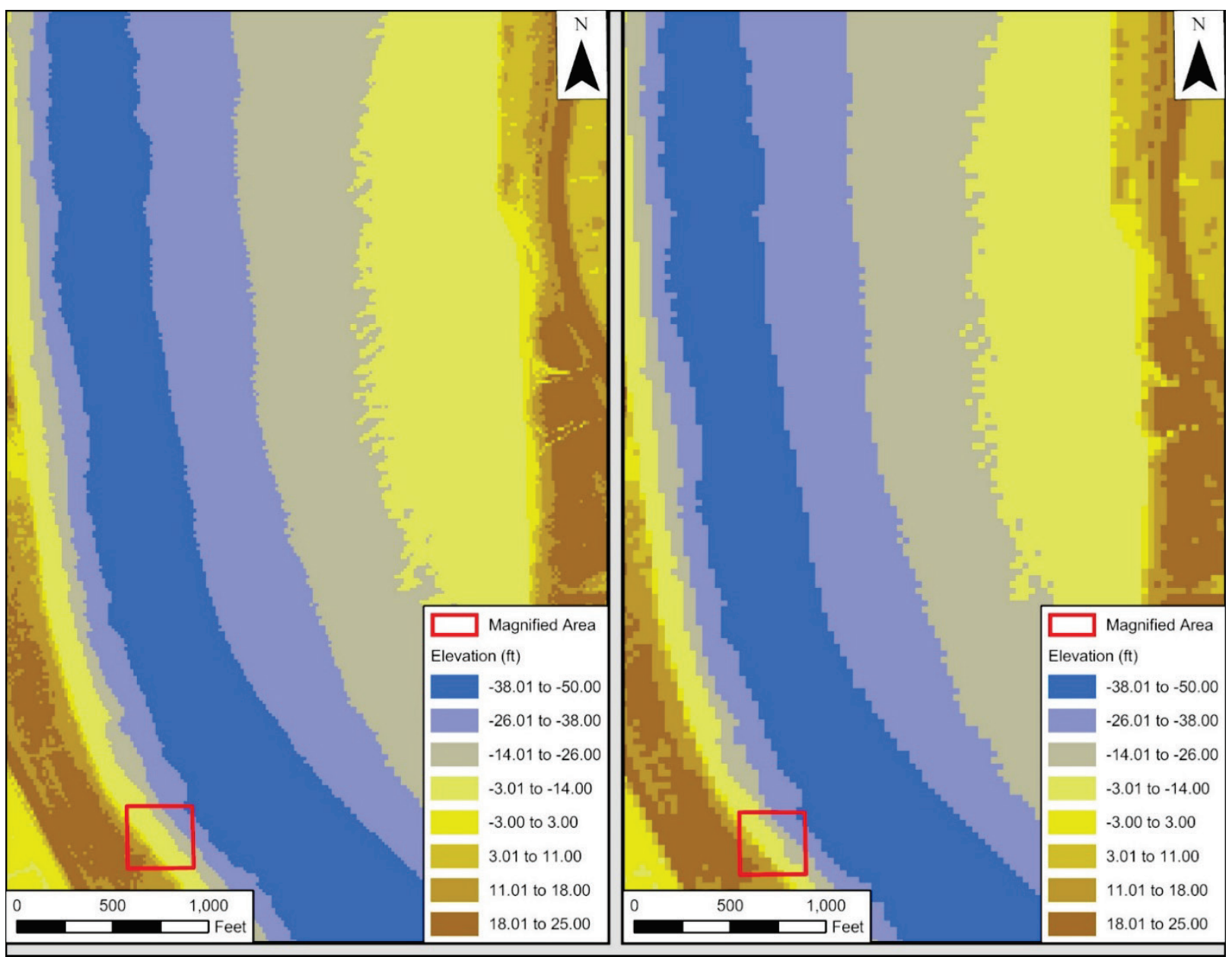

Elevation and bathymetric data at a scale of 1:9,000 show a cross section of the Mississippi River from levee to levee. Data in the upper left corner are at a spatial resolution of $5 \mathrm{~m}$, while data in the upper right corner have a resolution of $10 \mathrm{~m}$. To better display the increasing granularity associated with an increased spatial resolution, the bottom two images are at a scale of 1:1,000.
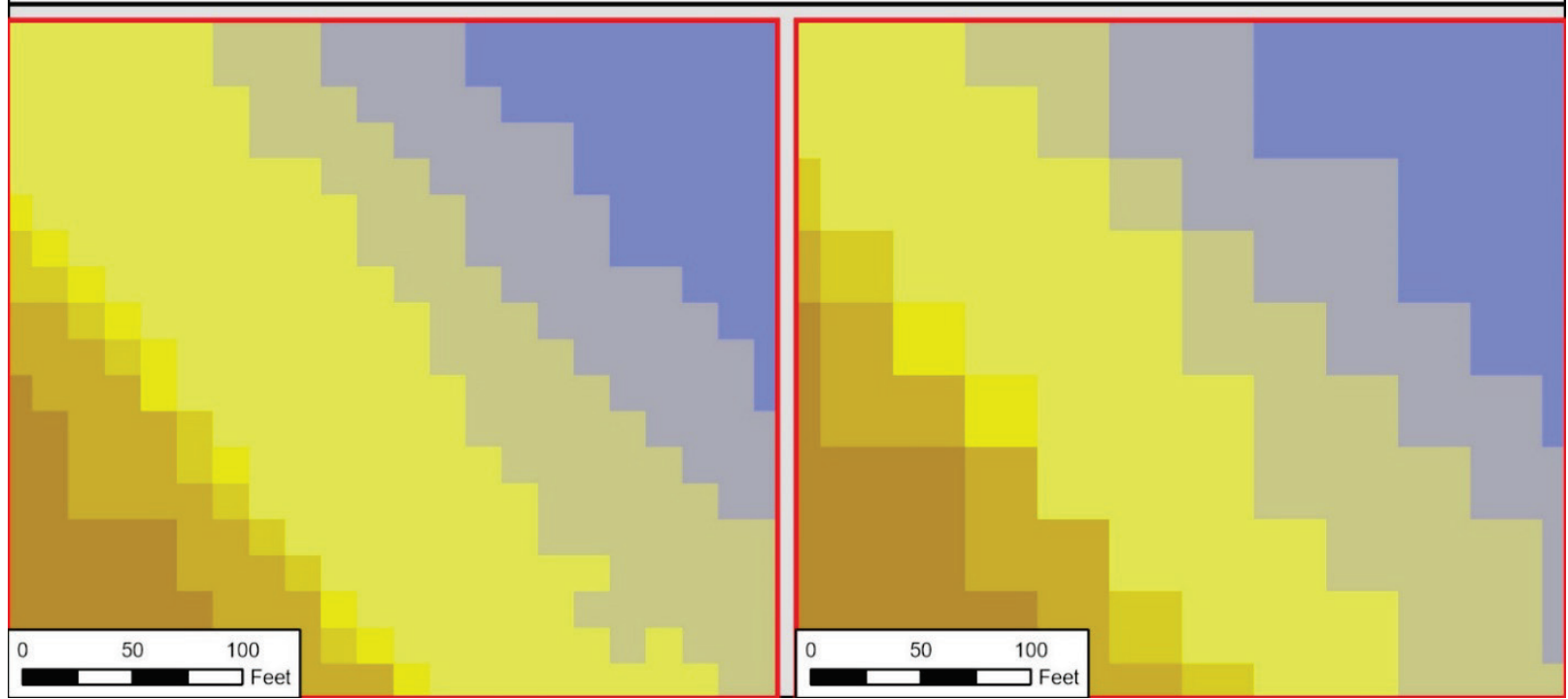

Figure 2. Five- and ten-meter resolution examples with larger scale insets outlined in red. 
The remaining three datasets were collected using LiDAR technology, which normally is acquired by an aircraft flying over the area of interest. A sensor emits pulses of light in a fan shape perpendicular to the flight of the aircraft. The time it takes for the sensor to record the return of the pulses of light can be used to determine the distance traveled. Ultimately, LiDAR provides not only measurements of the topography but also produces the capability to discern between natural and man-made structures based on reflective properties that affect the nature of the returned laser energy (Stevenson et al. 2013). An automated filtering process is combined with human visual quality control to pull out only those points representing the surface of the earth, known in this context as bare earth. These bare earth points are used to create the DEM.

The largest LiDAR dataset extended along 300 river miles from just west of Lake Mary in Mississippi to Venice, Louisiana, excluding the USACE Hurricane \& Storm Damage Risk Reduction System (HSDRRS) area in and around New Orleans, Louisiana, which just the year prior had a similar LiDAR dataset delivered. The data were collected over nine different dates between December 29, 2013, and February 15, 2014, using a Leica ALS70-CM laser scanner, which is designed to be mounted on a low-flying plane or helicopter. This sensor is specifically designed to generate an ultra-high density LiDAR point cloud over a corridor (Leica 2019).

The second LiDAR dataset was collected over the USACE HSDRRS that includes St. Charles, Jefferson, Orleans, St. Bernard, and Plaquemines Parishes in Louisiana, an area of nearly $419 \mathrm{mi}^{2}$. The data provide both bare earth and top surface feature elevation and is designed to provide input to hydrodynamic and numerical models, as well to perform economic related assessments. The data were collected between March 4, 2012, and March 25, 2012, with the final product exceeding the recommendations of the National Standard for Spatial Data Accuracy.

The final LiDAR dataset originated at Venice, Louisiana, and terminated where the river empties into the Gulf of Mexico. This covered $52 \mathrm{mi}^{2}$ of the Mississippi River Corridor's Southwest Pass, which has a linear area of nearly $21 \mathrm{mi}$. The data collection was sponsored by USACE MVN, and it was acquired between September 7, 2016, and September 9, 2016, using a Leica ALS70-CM laser scanner. All three LiDAR datasets were delivered at a spatial resolution of $1 \mathrm{ft}$ and in the State Plane Lousiana South projection.

Both sonar and LiDAR datasets elevation values are in the North American Vertical Datum of 1988 (NAVD88), which is based on the National Geodetic Survey 2013 update that used 2009 surveys performed as part of the Compehensive Evaluation of Project Datums, which became known as the NAVD88 2009.55 epoch (USACE MVN 2017), This revision is particularly important for the area from Venice, Louisiana, to the mouth of the Mississippi River at the end of the Southwest Pass due to subsidence, which is the downward movement of land in relation to sea level. Elevation values in NAVD88 are measured in feet. 


\section{MRG\&P}

\section{Mississippi River Geomorphology \& Potamology Program}

RESULTS: This project called for the creation of $1 \mathrm{~m}, 2 \mathrm{~m}, 5 \mathrm{~m}$, and $10 \mathrm{~m}$ seamless DEMs, but the data were in the State Plane Louisiana South projection, which measures units in feet (Figure 3). The native spatial resolution of the LiDAR data was $1 \mathrm{ft}$, and the sonar data spatial resolution was $2 \mathrm{ft}$. To create the seamless DEMs with spatial resolutions in each of the four measures in meters, the first step was to use the ESRI ArcMap Resample tool to create new rasters of the individual sonar and three LiDAR datasets at $1 \mathrm{~m}, 2 \mathrm{~m}, 5 \mathrm{~m}$, and $10 \mathrm{~m}$ spatial resolutions. In the resampling process, the nearest-neighbor algorithm for interpolation, which takes the value of the pixel in the input image closest to the computed coordinate, was used. This method is fast and does not change the original values of the pixels (Demirkesen 2008).

The next step for each of the $1 \mathrm{~m}, 2 \mathrm{~m}, 5 \mathrm{~m}$, and $10 \mathrm{~m}$ DEMs involved mosaicking the sonar and three LiDAR datasets of each spatial resolution together using the ArcMap Mosaic to New Raster tool. This is a straightforward process with the exception of choosing the pixel type, which controls the range of values that can appear in the raster. The 32-Bit Signed option was used, allowing the values to range from $-2,147,483,648$ to $2,147,483,647$. The output was a raster for each of the four cell sizes chosen that included all of the sonar and three LiDAR datasets. Due to the range of years and geographic area the data were collected over, there was not a built-in overlap of collection areas, which resulted in small areas of missing data across the DEMs.

The ArcGIS Con and Focal Statistics tools were used to create an expression where every cell in each of the four mosaicked rasters was first checked to determine whether it had a null value or an elevation associated with it. The vast majority of cells had an elevation value and were simply passed over by the Focal Statistics tool. When a cell with a null value was found, the Focal Statistics tool assigned a value to the null cell. To acquire this value, the average value for all cells within a 10-cell radius around the missing cell was calculated. This is an iterative process that continued until the missing areas were filled with estimated elevation values.

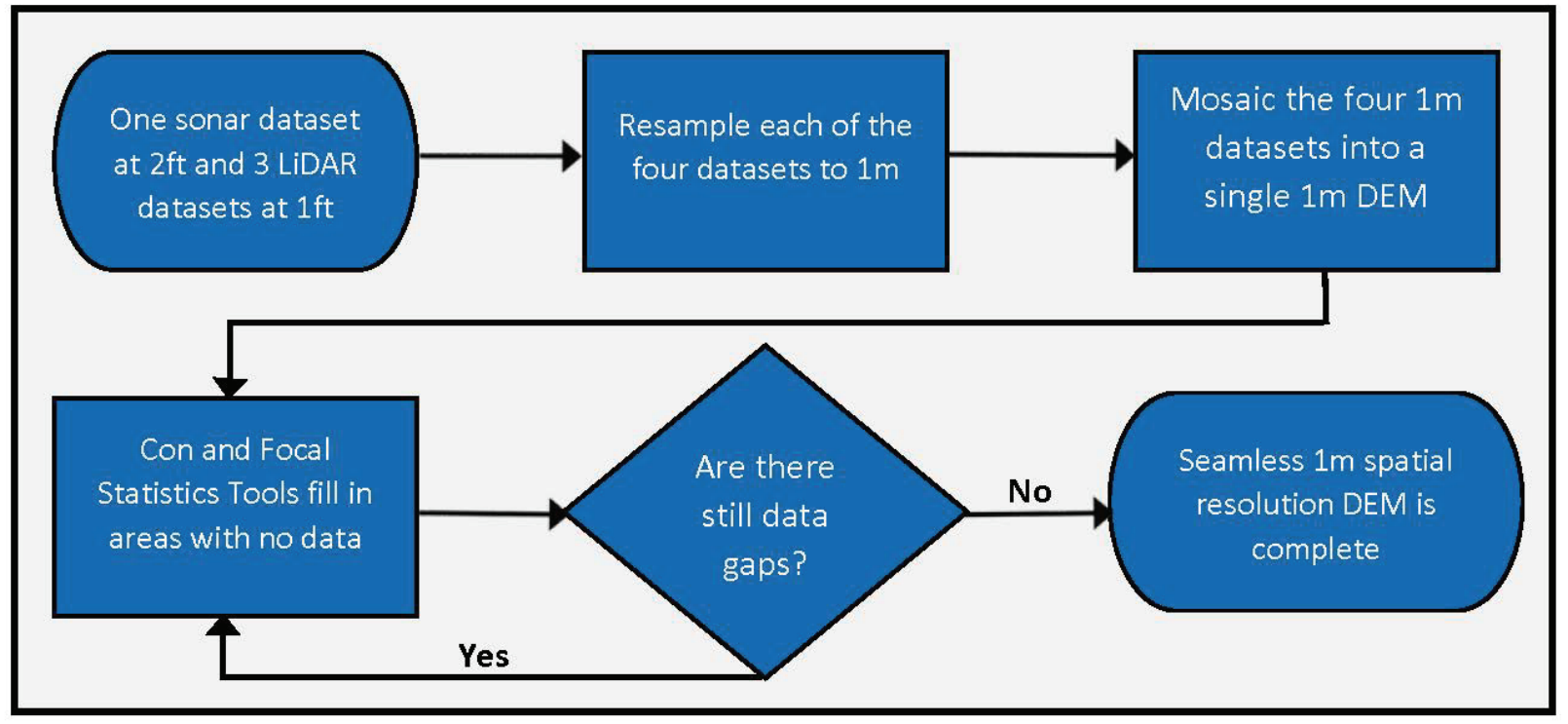

Figure 3. Flowchart showing the process for creating seamless DEM datasets. While the $1 \mathrm{~m}$ option is shown in the flowchart, the process was identical for the $2 \mathrm{~m}, 5 \mathrm{~m}$, and $10 \mathrm{~m}$ datasets. 
SUMMARY: Prior to the creation of these seamless DEM datasets, model inputs were based on whatever data the modeler could find. These datasets provide the most up-to-date source of elevation data, in mulitple spatial resolutions. This should make it easier for hydrologic modelers to compare their results to those of their peers.

\section{REFERENCES}

Bilskie, Matthew V., and Scott C. Hogan. 2013. "Topographic Accuracy Assessment of Bare Earth Lidar-Derived Unstructured Meshes." Advances in Water Resources 52: 165-177.

Deltares. 2020. Delft3D 4 Suite. Accessed 15 July. https://www.deltares.nl/en/software/delft3d-4-suite

Demirkesen, A. C. 2008. "Digital Terrain Analysis Using Landsat-7 ETM+ Imagery and SRTM DEM: A Case Study of Nevsehir Province (Cappadocia), Turkey." Internation Journal of Remote Sensing 29(14): 4173-4188 (4180). DOI 10.1080/01431160801891812.

ERDC (US Army Engineer Research and Development Center). March 6, 2014. The Adaptive Hydraulics (AdH) Modeling System. https://www.erdc.usace.army.mil/Locations/CHL/AdH/

ESRI (Environmental Systems Research Institute). 2016. ArcGIS for Desktop - Displaying the Raster's Spatial Resolution. http://desktop.arcgis.com/en/arcmap/10.3/manage-data/raster-and-images/displaying-therasters-spatial-resolution.htm

Leica. 2020. Leica ALS70 - Airborne Laser Scanners Performance for Diverse Applications. Accessed 15 July. https://w3.leicageosystems.com/downloads123/zz/airborne/ALS70/brochures/Leica_ALS70_6P_BRO_en.pdf

NOAA (National Oceanic and Atmospheric Administration). 2015. "How Multibeam Sonar Works." Ocean Explorer. http://oceanexplorer.noaa.gov/explorations/09bermuda/background/multibeam/multibeam.html

Stevenson, Terry H., Lori A. Magruder, Amy L. Neuenschwander, and Brian Bradford. 2013. "Automated Bare Earth Extraction Technique for Complex Topography in Light Detection and Ranging Surveys." Journal of Applied Remote Sensing 7: 1-13.

USACE HEC (US Army Corps of Engineers, Hydrolgic Engineering Center). 2020. US Army Corps of Engineers, Hydraulic Engineering Center. Accessed July 15. https://www.hec.usace.army.mil/software/hec-ras

USACE MVD (US Army Corps of Engineers, Mississippi Valley Division). 2020. US Army Corps of Engineers, Mississippi Valley Division Website. Accessed July 15. http://www.mvd.usace.army.mil/Missions/Mississippi-River-Science-Technology/MS-RiverGeomorphology-Potamology

USACE MVN (US Army Corps of Engineers, New Orleans District). 2017. Mississippi River Venice, Louisiana to the Gulf of Mexico (Vicinity of Southwest Pass, Louisiana. ERD-OD-01. New Orleans, LA: USACE MVN. http://www.mvn.usace.army.mil/Portals/56/docs/Navigation/EDRs/EDR-\%20SWP-\%20EDR-OD01,\%20Revision\%201\%20\%20(01-May-2017).pdf 